\title{
Comparing some anthropometric characteristics of the women according to various factors
}

\author{
H. Bayram Temur ${ }^{1 \mathrm{a}}$, Murat Avci ${ }^{1}$ and Mustafa Atli ${ }^{1}$ \\ ${ }^{1}$ Yüzüncü Y1l University, High school of Physical Education and Sports, Van,Turkey
}

\begin{abstract}
The purpose of this academic study is to compare some anthropometric characteristics of the women in respect of their playing football or not and waist. For this purpose, 63 women included 34 not doing sports and 29 playing football for different clubs in Van are incorporated into the study. The control group is choosen among the students of Yüzüncü Y1l University. Human subjects' average height is $160,62 \pm 5,52 \mathrm{~cm}$, average age is $19,87 \pm 2,50$ year and average weight is $54,78 \pm 9,26 \mathrm{~kg}$. Average sport history of the persons playing sport has been identified to be 4,31 $\pm 2,22$ year. Besides, the girt of breast, waist, hip, thighbone, calf has been measured. Vertical jumping, left and right hand grip strengths, resting heart pulse, body fat percentage, body fat mass, body mass index values were measured. For analysing these values, OneWay Anova and $t$ test were used. Consequently, it has been detected that there is significant difference on behalf of the women playing sport in vertical jumping length of football players and sedentery ones, at a level of $p<0,01$ between right and left hand grip strengths and $p<0.05$ in resting heart pulse variable and also there is not a significant difference $(\mathrm{p}<0,05)$ in other variables. . In addition, it is defined that there is significant $(p<0,01)$ relation between the thickness of waist and breast, hip, thighbone, calf, resting heart pulse, body weight, body fat percentage, body fat mass, body mass index values.
\end{abstract}

Keywords: Anthropometric measurement, football, resting heart pulse, waist thickness, hand grip strength, jumping strength.

\section{Introduction}

Inactivity, which is caused by industrialization and the modern lifestyle, at present negatively affects individuals of all age groups. A sedentary lifestyle also brings with it a number of serious health problems [1]. This sedentary lifestyle, which develops when energy intake exceeds expenditure as a result of energy imbalance, is a serious public health

\footnotetext{
${ }^{a}$ Corresponding author: temurbay@hotmail.com
} 
issue and decreases life expectancy and quality [2,3]. In particular, in situations where body weight exceeds the normal limits, along with a number of other serious health problems, a decrease in the capacity for physical labor is observed $[4,5]$.

Anthropometry is the measurement and evaluation of the physical dimensions, proportions and rough composition of the human body among all age groups. By comparing the data obtained with standards or reference data, nutrition and health conditions can be evaluated. Anthropometry is a simple and powerful estimator of individual and societal characteristics and shows the relationship between disease, health, functional disorders and mortality which can develop with advanced years. Anthropometric data are important for monitoring and identifying diseases. The results of anthropometric indicators can indicate change according to specific circumstances; these include biological changes related to age, diseases, cohort effects, century-old tendendencies, diseases experienced in childhood, smoking, diet, exercise and socioeconomic factors [6].

During exercise the circulatory system transports blood to tissues as necessary. It holds an otherwise increasing body temperature constant. Regular workouts increase the volume of cardiac output. A minor increase in pulse is observed. The pulse decreases to 60 beats/minute. It has been determined that the lowest level a pulse can be reduced to is 30 beats/minute. During exertion, the return to a normal heart rate is faster in athletes compared with non-athletes [Sevim, 1997].

During high intensity exercise fats, by being mobilized, are hydrolyzed and provide energy. Studies have shown that during exercise, at maximum level VO2 of $85 \%$, fat oxidation increases significantly [8, 9]. Regular exercise programs change the composition of the body. Cardiovascular training and weight training decrease body mass [10].

Exercise programs are used not only to improve performance but also to correct the energy balance disrupted in the treatment of excess weight. Either exercise or diet or both together can be carried out with this goal. Some researchers have determined that in weight loss obtained solely by means of dieting not only fat but also fat-free body mass is lost [11]. Gibson [1990] reported that the measurement of the subcutaneous tissue in the waist circumference, hip cirumference, waist/hip ratio, biceps, triceps, and subscapular and suprailiac regions was a conventional method for determining fat distribution in the body. In recent years measurement of the waist circumference has begun to be widely used [13]. The waist circumference is the best reflection of the fat which accumulates in the abdominal region, both visceral and subcutaneous, and the muscle tone of the abdomen [14].

The sport of football (soccer) requires technical skill and relies on anthropometric and physiological parameters which are tied as much to psychological factors as to technical skill [15]. There are three important elements which determine performance level in football: technique, tactics, and a player's condition; according to a comparison made of each of these, they may all play roles, to varying degrees, in a player's success [İşleğen, 1987]. Of these three elements, condition carries greater than $50 \%$ importance in a player's performance [Temoçin, 2004]. In addition to technique and tactics in football, physiological anthropometric characteristics also affect players' performances. In particular, performance is directly correlated with the generation of strength, height, body mass, lengths of arms and legs, joint mobility, and level of flexibility [Eker et al., 2003].

The aim of this study is to compare some anthropometric characteristics of female football (soccer) players with those of sedentary females in the same age group. 


\section{Method}

The study was carried out on 63 female students attending Yuzuncu Y1l University, 29 of whom are football players and 34 of whom are sedentary. Descriptive information on the subjects and the measurement gathering methods are presented below.

Table 1. Descriptive information regarding the study subjects

\begin{tabular}{lccccc}
\hline & N & $\begin{array}{c}\text { Age (years) } \\
\text { Mean } \pm \text { MD }\end{array}$ & $\begin{array}{c}\text { Height (cm) } \\
\text { Mean } \pm \text { MD }\end{array}$ & $\begin{array}{c}\text { Body weight } \\
(\mathbf{k g} \text { Mean } \pm \\
\text { MD }\end{array}$ & $\begin{array}{c}\text { Background in } \\
\text { sports (years) } \\
\text { Mean } \pm \text { MD }\end{array}$ \\
\hline $\begin{array}{l}\text { Football players } \\
\text { Sedentary }\end{array}$ & 29 & $18,62 \pm 2,73$ & $160,55 \pm 5,45$ & $53,59 \pm 7,39$ & $4,31 \pm 2,22$ \\
$\begin{array}{l}\text { subjects } \\
\text { Total }\end{array}$ & 63 & $20,94 \pm 1,69$ & $160,68 \pm 5,67$ & $55,80 \pm 10,60$ & - \\
\hline
\end{tabular}

Anthropometric measurements are important as an indicator of protein and fat deposits in determining an individual's nutritional condition. Growth and body composition, body weight, height, Body Mass Index (BMI), diameter and circumference measurements (waist circumference, hip circumference, waist/hip ration, overarm length, calf circumference, etc.), skin fold thickness, bioelectrical impedance (BIA) and determination of body fat percentage and fat-free body mass are commonly used anthropometric methods [Pekcan, 2000; Küçükkömürler, 2001; Bilgiç, 2003]. Fat distribution concentrated in the body is correlated with disease and therefore the risk of death. Fat stored in the upper portion of the body (android or apple-shaped) is known to represent a greater risk than fat stored in the lower portion of the body such as the thighs and hips (gynoid or pear-shaped). In recent years, measurement of the waist circumference alone, based on these data, has been used as an indicator of the accumulation of abdominal fat and therefore of deterioration in health [6, 23]. In healthy adults, although BMI has been accepted as a good indicator to evaluate body fat percentage, it has been shown not to be a suitable method of measurement for young subjects; in particular, in sedentary youths body fat is more accurately reflected by BIA than by BMI [24]. Because of this, in this study we compared anthropometric measurements in both football players and in sedentary subjects, and also compared them with waist circumference values.

\subsection{Data Gathering Method}

Meters were used to measure the heights of the subjects. Chest, waist, hip, thigh and calf circumference measurements where taken with a non-stretching measuring tape, while hand grip strength was measured using the Takkei Physical Fitness Test Grip-D (Grip Strength Dynamometer, made in Japan) brand hand dynamometer. Vertical jump test values were determined using the Takkei Physical Fitness Test Jump - MD (T.K.K. 5106) brand jump meter. Body weight, fat percentage, body fat mass and Body Mass Index were determined with the Jawon AVIS 333 PLUS Body Analysis Device.

\subsection{Measurement Methods}

\subsubsection{Height}

Height measurements were taken as meters with the subjects standing erect in bare feet. 


\subsubsection{Body Weight}

Body weight was measured with a sensitive electronic scale with the subjects in bare feet and wearing only bathing suitsbare feet.

\subsubsection{Left-Right Hand Grip Strength Measurements}

For this measurement, the "Grip Strength Dynamometer Grip-D" brand dynamometer was used. The subjects gripped the device while standing without bending their elbows or touching the body; the measurement was taken with the the side with the indicator turned toward the test subject, who applies only grip strength. Measurements were taken twice for each hand and the best measurement for each was recorded.

\subsection{Circumference measurements:}

\subsubsection{Waist circumference:}

Waist circumference was taken measuring the narrowest circumference between the lowest rib and the process of the anterior superior iliac spine above the navel parallel to the floor using a transfer tape measure [25].

\subsubsection{Waist, Hip and Calf circumferences and overarm length:}

Waist and hip circumferences were taken with the subjects standing with arms by their sides, feet close to each other and with equal weight on each foot.

\subsubsection{Thigh circumference:}

Subjects were requested to stand with their feet apart at shoulder width. One measurement was taken at the widest point near the groin (at maximum quadriceps extension). The second measurement was taken with the thigh muscles contracted (at maximum quadriceps contraction) at the same location.

\subsubsection{Calf circumference:}

The measurement was taken using a non-stretching tape measure parallel to the floor at the widest point of the calf.

\subsection{Resting Heart Rate Measure}

In determining the resting heart rate the carotid artery in the neck was used. After the subjects rested in a chair for $5-10$ minuntes the pulse was measured for 15 seconds, multiplied by four (beats/minute) and the results were recorded.

\subsection{Statistical Analysis}

The data obtain were analyzed using the IBM SPSS Statistics 21 software package. Fitness of the data to normal distribution was examined emplying the One-Sample KolmogorovSmirnov test. Analysis of variables was performed using the t-test and One-Way Anova test. 


\section{Findings}

Table 2. The distribution of some variables in football players and sedentary subjects

\begin{tabular}{|c|c|c|c|c|c|c|c|}
\hline Variables & $\begin{array}{l}\text { Sport } \\
\text { participation }\end{array}$ & $\mathbf{N}$ & Mean & MD & SD & $\mathbf{t}$ & $\mathbf{p}$ \\
\hline Chest & Football & 29 & 84,07 & 6,95 &,- 190 & 61 & 850 \\
\hline circumference $(\mathrm{cm})$ & Sedentary & 34 & 84,41 & 7,29 & & & \\
\hline Waist & Football & 29 & 69,34 & 4,46 & & & \\
\hline $\begin{array}{l}\text { circumference } \\
\text { measurement }\end{array}$ & Sedentary & 34 & 68,26 & 7,49 & ,680 & 61 & ,499 \\
\hline $\begin{array}{l}\text { Hip circumference } \\
(\mathrm{cm})\end{array}$ & $\begin{array}{l}\text { Football } \\
\text { Sedentary }\end{array}$ & $\begin{array}{l}29 \\
34\end{array}$ & $\begin{array}{l}93,41 \\
96,35\end{array}$ & $\begin{array}{l}5,70 \\
7,64\end{array}$ & $-1,705$ & 61 & ,093 \\
\hline $\begin{array}{l}\text { Thigh } \\
\text { circumference }(\mathrm{cm})\end{array}$ & $\begin{array}{l}\text { Football } \\
\text { Sedentary }\end{array}$ & $\begin{array}{l}29 \\
34\end{array}$ & $\begin{array}{l}54,72 \\
53,56\end{array}$ & $\begin{array}{l}4,14 \\
7,23\end{array}$ &, 767 & 61 & ,446 \\
\hline $\begin{array}{l}\text { Calf circumference } \\
(\mathrm{cm})\end{array}$ & $\begin{array}{l}\text { Football } \\
\text { Sedentary }\end{array}$ & $\begin{array}{l}29 \\
34\end{array}$ & $\begin{array}{l}34,27 \\
33,97\end{array}$ & $\begin{array}{l}3,06 \\
3,93\end{array}$ & ,340 & 61 & ,735 \\
\hline Vertical jump (cm) & $\begin{array}{l}\text { Football } \\
\text { Sedentary }\end{array}$ & $\begin{array}{l}29 \\
34\end{array}$ & $\begin{array}{l}38,06 \\
30,29\end{array}$ & $\begin{array}{l}7,20 \\
5,03\end{array}$ & 5,023 & 61 &, 000 \\
\hline $\begin{array}{l}\text { Resting heart rate } \\
\text { (beats } / \mathrm{min} \text { ) }\end{array}$ & $\begin{array}{l}\text { Football } \\
\text { Sedentary }\end{array}$ & $\begin{array}{l}29 \\
34\end{array}$ & $\begin{array}{l}75,45 \\
84,41\end{array}$ & $\begin{array}{l}12,86 \\
16,06\end{array}$ & $-2,416$ & 61 & ,019 \\
\hline $\begin{array}{l}\text { Right hand grip } \\
\text { (kg) }\end{array}$ & $\begin{array}{l}\text { Football } \\
\text { Sedentary }\end{array}$ & $\begin{array}{l}29 \\
34\end{array}$ & $\begin{array}{l}28,91 \\
25,52\end{array}$ & $\begin{array}{l}4,80 \\
4,00\end{array}$ & 3,052 & 61 &, 003 \\
\hline Left hand grip $(\mathrm{kg})$ & $\begin{array}{l}\text { Football } \\
\text { Sedentary }\end{array}$ & $\begin{array}{l}29 \\
34\end{array}$ & $\begin{array}{l}27,64 \\
24,75\end{array}$ & $\begin{array}{l}3,62 \\
3,10\end{array}$ & 3,405 & 61 &, 001 \\
\hline Body Weight (kg) & $\begin{array}{l}\text { Football } \\
\text { Sedentary }\end{array}$ & $\begin{array}{l}29 \\
34\end{array}$ & $\begin{array}{l}53,59 \\
55,80\end{array}$ & $\begin{array}{c}7,39 \\
10,60\end{array}$ &,- 944 & 61 & ,349 \\
\hline $\begin{array}{l}\text { Body Fat } \\
\text { Percentage }(\%)\end{array}$ & $\begin{array}{l}\text { Football } \\
\text { Sedentary }\end{array}$ & $\begin{array}{l}29 \\
34\end{array}$ & $\begin{array}{l}22,43 \\
23,34\end{array}$ & $\begin{array}{l}4,38 \\
6,41\end{array}$ &,- 649 & 61 &, 519 \\
\hline Body fat mass (kg) & $\begin{array}{l}\text { Football } \\
\text { Sedentary }\end{array}$ & $\begin{array}{l}29 \\
34\end{array}$ & $\begin{array}{l}12,32 \\
13,57\end{array}$ & $\begin{array}{l}3,76 \\
6,59\end{array}$ &,- 903 & 61 &, 370 \\
\hline $\begin{array}{l}\text { Lean body mass } \\
(\mathrm{kg})\end{array}$ & $\begin{array}{l}\text { Football } \\
\text { Sedentary }\end{array}$ & $\begin{array}{l}29 \\
34\end{array}$ & $\begin{array}{l}40,68 \\
42,23\end{array}$ & $\begin{array}{l}6,94 \\
4,55\end{array}$ & $-1,062$ & 61 & ,292 \\
\hline $\begin{array}{l}\text { Body mass index } \\
\left(\mathrm{kg} / \mathrm{m}^{2}\right)\end{array}$ & $\begin{array}{l}\text { Football } \\
\text { Sedentary }\end{array}$ & $\begin{array}{l}29 \\
34\end{array}$ & $\begin{array}{l}20,90 \\
21,58\end{array}$ & $\begin{array}{l}2,23 \\
3,91\end{array}$ &,- 838 & 61 & ,405 \\
\hline
\end{tabular}

In Table 2, a statistical comparison of some variables for the female football players and non-athletes are presented. According to the data, no statistical significance was found between the values for waist, hip, chest, calf, and thigh circumferences, body mass, body fat mass, fat-free body mass, and Body Mass Index values for the two groups $(p<0.05)$. However, the difference between resting heart rate values at a level of $p<0.05$, and vertical jump test and left and right hand grip strength values at a level of $p<0.01$, were significantly different, with the athletes having higher values.

In Table 3, a statistical analysis of the average waist circumference values together with some variables are presented. According to the data, while the average values for waist, chest, hip, thigh, and calf circumferences, resting heart rate, body mass, body fat mass, body fat percentage, and Body Mass Index are at a level $\mathrm{p}<0.01$, the average left hand grip strength was found to correlate with $p<0.05$. In spite of these results, the average values for vertical jump test and right hand grip strength were not determined to be significant $(\mathrm{p}<0.05)$. 
Table 3. The distribution of different variables according to waist circumference measurements

\begin{tabular}{|c|c|c|c|c|c|c|}
\hline Variables & $\begin{array}{l}\text { Sources of } \\
\text { variance }\end{array}$ & $\begin{array}{l}\text { Sum of } \\
\text { Squares }\end{array}$ & df & $\begin{array}{l}\text { Mean } \\
\text { Square }\end{array}$ & $\mathbf{F}$ & $\mathbf{p}$ \\
\hline \multirow{4}{*}{$\begin{array}{l}\text { Chest circumference } \\
\text { (cm) }\end{array}$} & Between Groups & 1844,713 & 4 & 461,178 & \multirow{3}{*}{21,108} & \multirow{3}{*}{, 000} \\
\hline & Within Groups & 1267,223 & 58 & 21,849 & & \\
\hline & Total & 3111,937 & 62 & & & \\
\hline & Between Groups & 2006,825 & 4 & 501,706 & \multirow{3}{*}{30,149} & \multirow{3}{*}{, 000} \\
\hline \multirow{2}{*}{$\begin{array}{l}\text { Hip circumference } \\
(\mathrm{cm})\end{array}$} & Within Groups & 965,175 & 58 & 16,641 & & \\
\hline & Total & 2972,000 & 62 & & & \\
\hline \multirow{3}{*}{$\begin{array}{l}\text { Thigh circumference } \\
(\mathrm{cm})\end{array}$} & Between Groups & 1461,191 & 4 & 365,298 & \multirow{3}{*}{27,651} & \multirow{3}{*}{, 000} \\
\hline & Within Groups & 766,238 & 58 & 13,211 & & \\
\hline & Total & 2227,429 & 62 & & & \\
\hline \multirow{3}{*}{$\begin{array}{l}\text { Calf circumference } \\
(\mathrm{cm})\end{array}$} & Between Groups & 472,216 & 4 & 118,054 & \multirow{3}{*}{22,823} & \multirow{3}{*}{, 000} \\
\hline & Within Groups & 300,006 & 58 & 5,173 & & \\
\hline & Total & 772,222 & 62 & & & \\
\hline \multirow{3}{*}{$\begin{array}{l}\text { Resting heart rate } \\
\text { ( beats/min) }\end{array}$} & Between Groups & 4070,811 & 4 & 1017,703 & \multirow{3}{*}{5,715} & \multirow{3}{*}{,001 } \\
\hline & Within Groups & 10328,046 & 58 & 178,070 & & \\
\hline & Total & 14398,857 & 62 & & & \\
\hline \multirow[t]{3}{*}{ Vertical jump (cm) } & Between Groups & 303,165 & 4 & 75,791 & \multirow{3}{*}{1,500} & \multirow{3}{*}{,214 } \\
\hline & Within Groups & 2929,819 & 58 & 50,514 & & \\
\hline & Total & 3232,984 & 62 & & & \\
\hline \multirow{4}{*}{ Right hand grip (kg) } & Between Groups & 64,435 & 4 & 16,109 & \multirow{3}{*}{, 724} & \multirow{3}{*}{,579 } \\
\hline & Within Groups & 1290,247 & 58 & 22,246 & & \\
\hline & Total & 1354,682 & 62 & & & \\
\hline & Between Groups & 122,562 & 4 & 30,641 & \multirow{3}{*}{2,563} & \multirow{3}{*}{, 058} \\
\hline \multirow[t]{2}{*}{ Left hand grip (kg) } & Within Groups & 693,402 & 58 & 11,955 & & \\
\hline & Total & 815,964 & 62 & & & \\
\hline \multirow[t]{3}{*}{ Body Weight (kg) } & Between Groups & 3940,506 & 4 & 985,127 & \multirow{3}{*}{41,586} & \multirow{3}{*}{, 000} \\
\hline & Within Groups & 1373,945 & 58 & 23,689 & & \\
\hline & Total & 5314,451 & 62 & & & \\
\hline Body Fat Percentage & Between Groups & 1360,208 & 4 & 340,052 & & \\
\hline$(\%)$ & Within Groups & 544,555 & 58 & 9,389 & 36,219 & ,000 \\
\hline & Total & 1904,763 & 62 & & & \\
\hline Body fat mass (kg) & Between Groups & 1551,924 & 4 & 387,981 & & \\
\hline & Within Groups & 302,024 & 58 & 5,207 & 74,507 & ,000 \\
\hline & Total & 1853,949 & 62 & & & \\
\hline Body mass index & Between Groups & 530,924 & 4 & 132,731 & & \\
\hline$(\mathrm{kg} / \mathrm{m} 2)$ & Within Groups & 120,913 & 58 & 2,085 & 63,669 & ,000 \\
\hline & Total & 651,837 & 62 & & & \\
\hline
\end{tabular}

\section{Discussion}

In this study which compared the anthropometric characteristics of 29 female athletes, who had been playing football for an average of $4.31 \pm 2.22$ years, with 34 sedentary women, measurements were taken of the subjects' height and weight, along with chest, waist, hip, thigh and calf circumferences. In addition, values for the vertical jump test, right and left hand grip strength, resting heart rate, body fat percentage (BFP), body fat mass (BFM) and Body Mass Index were determined. The values obtained were compared with those of other studies in this field.

When the chest circumference measurements for the football players and sedentary subjects were examined, it was found that the former group had an average chest circumference of $84.07 \pm 6.95 \mathrm{~cm}$, while the average for the latter group was $84.41 \pm 7.29$ $\mathrm{cm}$. In a study involving university students [Eker et al., 2003], it was determined that the test groups did not have a significant difference in chest circumference $(p<0.05)$.

The average waist circumference for football players and sedentary subjects taken together was $68.76 \pm 6.26 \mathrm{~cm}$. No statistically significant difference in these values was observed between the two groups $(\mathrm{p}<0.05)$. Biçer et al. [2005] reported that there was no significant difference between waist circumference measurements taken prior to and 
following 12 weeks of exercise. Ergün and Erte [2004], in their study with university students, found that the average waist circumference measurement in females was $67.01 \pm$ $6.36 \mathrm{~cm}$. Eker et al. [2003] reported no significant difference in the waist circumference measurements made in their study. In addition, they stated that waist circumference should not exceed $102 \mathrm{~cm}$ in males and $88 \mathrm{~cm}$ in females [23]. Research findings in the literature exhibit similar results.

The average hip circumference measurement for the athletes was $93.41 \pm 5.70 \mathrm{~cm}$, while the average for the sedentary subjects was $96.35 \pm 7.64 \mathrm{~cm}$. In spite of increased average hip circumference measurements seen in the sedentary subjects, the increase is not statistically significant $(p<0.05)$. Biçer et al. [2005] revealed in their study that the difference in hip circumference measurements taken prior to starting and after finishing an exercise program was not statistically significant $(\mathrm{p}<0.05)$. These data correspond with our findings. It is thought that the fact that the control group consists of students of low average age is influential in these results. In other words, the fact that the subjects are both young and students points to their being more active.

For both groups taken together the average thigh circumference measurement was 54.09 $\pm 5.99 \mathrm{~cm}$. Although the average thigh circumference measurement for the football players was greater $(54.72 \pm 4.14 \mathrm{~cm}$, versus $53.56 \pm 7.23 \mathrm{~cm}$ for the sedentary subjects), the difference was found not to be statistically significant $(\mathrm{p}<0.05)$. This can be explained by the fact that there was no statistically significant difference between body fat percentages in the two groups and that the football players are subjected to more technical rather than intensive training.

The average calf circumference measurement for the two groups was determined to be $34.11 \pm 3.53 \mathrm{~cm}$. When the calf circumference measurements were examined, the average for the athletes was $34.27 \pm 3.06 \mathrm{~cm}$ while the average for the sedentary subjects was 33.97 $\pm 3.93 \mathrm{~cm}$. Although the average calf circumference of the athletes was greater, the difference is not statistically significant $(\mathrm{p}<0.05)$. Eker et al. [2003] argued that there was no difference in calf circumference measurements between groups in their study. This also supports our findings.

While the average vertical jump test value for the athletes was $38.07 \pm 7.20 \mathrm{~cm}$, it was $30.29 \pm 5.03 \mathrm{~cm}$ for the sedentary subjects. These values indicate a statistically significant difference $(p<0.01)$. Zorba et al. [2000] assigned women between the ages of $18-24$ to an 8 -week-long step exercise program 3 days a week and found that at the end of the study period the vertical jump test results for the test group increased significantly. Çolakoğlu and Karacan [2006] also revealed that their study found a significant difference in vertical jump test results after the subjects participated in a 12-week exercise program. However much of a correlation between thigh and calf circumferences and jumping has been propounded by studies [29, 30], this may not be valid for all situations and conditions. If the fact that there is no significant difference in our study in the thigh and calf circumferences of the two groups is taken into consideration, this difference in jump results cannot be explained by the development of leg muscles such as the quadriceps, hamstrings, and soleus. Here, we are of the view that it is more correct to explain this result by considering other factors affecting jumping such as the ability to swing the arms, density of the muscle type (white or red), and technique.

Average resting heart rate was $75.45 \pm 12.86$ beats/min. for the athletes and $84.41 \pm$ 16.06 beats $/ \mathrm{min}$. for the sedentary subjects. When these values were compared the difference was observed to be significant at a level of $p<0.05$. Other studies on this topic (Fonong, 1998; Rognmo et al., 2004) have proposed that exercise decreases the blood pressure and heart rate (HR). In a study by Hoeger (1991), it was asserted that a resting heart rate of 59 beats $/ \mathrm{min}$. or less is ideal, $60-69$ is good, $70-79$ is average, $80-89$ is weak, and 90 or above is very weak. Another study on this topic was carried out by Parker 
et al. (1991). They reported that in the course of submaximal walking, the average heart rate measurements decreased from $135-120$ beats $/ \mathrm{min}$. to $108-104$ beats $/ \mathrm{min}$. Erdoğan et al. (1981), in their study in which they compared respiratory and circulation parameters of athletes in various sports with those of sedentary people during rest, exercise, and recovery, reported that the resting pulse rates of athletes were significantly lower than those of the control group. The literature supports the findings obtained by the present study. This difference in heart rate is a natural result of developing hypertrophy of the heart.

The average right hand grip strength was $28.91 \pm 4.80 \mathrm{~kg}$ for the football players and $25.52 \pm 4.00 \mathrm{~kg}$ for the sedentary subjects. The average left hand grip strength was 27.64 $\pm 3.62 \mathrm{~kg}$ for the football players and $24.75 \pm 3.10 \mathrm{~kg}$ for the sedentary subjects. The differences in the averages of both right and left hand grip strengths were found to statistically significant when the two groups were compared $(\mathrm{p}<0.01)$, with those of the athletes being greater. Saka et al. (2008) determined in their study that both right and left hand grip strengths increased at a significant level when measurements taken before and after participation in an exercise program were compared $(\mathrm{p}<0.01)$. In another study (Blake et al., 2000), obese and normal weight sedentary women were assigned a 14-week exercise program; the responses of each group to exercise and their physical fitness levels were compared. A positive change in grip strength values was recorded. Our study findings show parallels with those reported in the literature. Along with development of arm muscles, it is thought that the subjects' Bone Mineral Density (BMD) also had an effect. Temur (2012) reported in his study involving young males that BMD had a significant correlation with grip strength.

When the body fat percentages of the subjects are examined by group that of the football players was found to be $22.43 \pm 4.38 \%$ while that of the sedentary group was 23.34 $\pm 6.41 \%$. Despite the fact that body fat percentage was higher among the sedentary subjects, the difference was not determined to be statistically significant $(p<0.05)$. Alphan (2003) stated that body mass is composed of the totality of bones, teeth, muscles, organs, fluids and adipose tissue. According to him, these components all show variation based on each individual's age, growth, fertility, and level of physical activity, with adipose tissue generally known as fat mass, while the other components are fat-free mass. It has been reported that body fat percentage decreases and body composition is positively affected by training done three times a week for twenty minutes, with maximum $\mathrm{VO} 2$ above $50 \%$ (A.C.S.M., 1990). Amano et al. (2001) also found in their study that prior to undertaking an exercise program, their subjects' average body fat percentage was $29.6 \% \pm 1.3$, and 26.6 $\pm 1.3 \%$ after finishing the program and reported that this decrease was significant. Gökdemir (2007) reported that the difference in the pre- and post-study body fat percentages of the 30 healthy subjects in his study, composed of 15 test and 15 control group subjects averaging 21 years in age, determined to be $8.8 \pm 1.1 \%$ and $7.8 \pm 1.0 \%$, respectively, was significant. Saka et al. (2008), in their study involving men between the ages of $23-25$, also stated that the post-study body fat percentages showed a significant decrease $(p<0.01)$. The present study data are in agreement with some studies in the literature but contradict others. The difference in the results obtained may have been affected by the low average age $(19.87 \pm 2.50)$ of the subjects in the present study.

Examining the average body fat mass values, it is observed that the difference between that of the sedentary group $(13.57 \pm 6.59 \mathrm{~kg})$, despite being higher than that of the football players $(12.32 \pm 376 \mathrm{~kg})$, is not greater to a statistically significant degree $(\mathrm{p}<0.05)$. In their study, Biçer et al. (2005) reported that average fat mass measurements decreased from $26.77 \mathrm{~kg}$ prior to the exercise program to $23.28 \mathrm{~kg}$ afterwards. Their findings were similar to those of the present study as a consequence of the fat percentages of the football players being lower. Zorba (2001) asserted that exercise reduces body fat mass. However, he pointed out that the degree of this decrease is connected to the type, intensity and frequency 
of exercise. He furthermore emphasized that the body fat percentages of female athletes are quite variable and vary according to the actual athletic discipline being engaged in. Nonetheless, the fact that our findings were not statistically significant is thought to be a result of the young average age of the sedentary group.

When average fat-free body mass is examined by group, the difference between that of the football players $(40.68 \pm 6.94 \mathrm{~kg})$ and sedentary women $(42.23 \pm 4.55)$ was determined not to be statistically significant $(\mathrm{p}<0.05)$. The number of studies showing that exercise performed regularly and in controlled conditions decreases body fat and increases lean body mass is constantly on the rise. However, there is a difference in response of individuals of different age groups and body compositions [42].

Looking at the average Body Mass Index (BMI) values of each group, that of the football players was calculated to be $20.89 \pm 2.23 \mathrm{~kg} / \mathrm{m} 2$ while that of the sedentary subjects was $21.58 \pm 3.91 \mathrm{~kg} / \mathrm{m} 2$. Although the average BMI of the football players was lower, the difference between the average values for each group was not found to be statistically significant $(\mathrm{p}<0.05)$. In one study, Koca $(2003)$ found that the average BMI of test subjects prior to starting an exercise program was $20.1 \pm 2.0 \mathrm{~kg} / \mathrm{m} 2$ and $20.1 \pm 1.5$ $\mathrm{kg} / \mathrm{m} 2$ after finishing the program; this difference was found to be statistically insignificant $(p>0,05)$. Biçer et al. (2005) in their study concluded that the difference in average BMI of the subjects before and after participating in an exercise program was not significant. The results obtained in the present study are in agreement with those of other studies reported in the literature. A natural decrease in BMI is expected following the adoption of a regular exercise program. Given the statistical insignificance of the decrease in average BMI values of the test group in our findings, rather than engaging test subjects in high-intensity training, it is thought that training oriented more towards enhancement of technique may be more effective. Üstündal and Köker (1998) observed that "Body mass and composition are related to an athlete's genetics, diet and training, and his/her final physical composition is an indicator both of his/her genetic characteristics and of the changes resulting from training at a high level."

Chest circumference measurements of the subjects were examined according to the waist circumference measurements. The average chest circumference was found to be $84.25 \pm 7.08 \mathrm{~cm}$. These average values show an increase corresponding to the increased waist circumference measurements. Subjects with a waist circumference between 60 and $66 \mathrm{~cm}$ had an average chest circumference of $80.04 \pm 4.05 \mathrm{~cm}$, while those with a waist circumference of $85 \mathrm{~cm}$ or greater had an average chest circumference of $102.00 \pm 4.24$ $\mathrm{cm}$. These values were determined to be statistically significant $(\mathrm{p}<0.01)$.

The average hip circumference of all subjects participating in the study was $95.00 \pm$ $6.92 \mathrm{~cm}$. An increase in hip circumference measurements was also found to correspond to an increase in average waist circumference. For example, subjects with a waist circumference between 60 and $66 \mathrm{~cm}$ had an average hip circumference of $90.13 \pm 3.76 \mathrm{~cm}$, while those with a waist circumference of $85 \mathrm{~cm}$ or greater had an average hip circumference of $115.00 \pm 5.66 \mathrm{~cm}$. When these values were compared they were shown to be statistically significant at a level of $\mathrm{p}<0.01$.

The average thigh circumference of all the study participants was $54.09 \pm 5.99 \mathrm{~cm}$. The distribution of this measurement with regard to waist circumference is as follows: subjects with a waist circumference between 60 and $66 \mathrm{~cm}$ had an average thigh circumference of $49.17 \pm 3.30 \mathrm{~cm}$, while those with a waist circumference of 85 or greater had an average thigh circumference of $71.00 \pm 1.41 \mathrm{~cm}$. The average calf circumference of all subjects was $34.11 \pm 3.53 \mathrm{~cm}$. These values show a corresponding increase with waist circumference. Those individuals with the lowest waist circumference $(60-66 \mathrm{~cm})$ had an average calf circumference of $31.52 \pm 2.64 \mathrm{~cm}$, while that of individuals with the highest waist circumference $(85 \mathrm{~cm}$ and over) was $43.50 \pm 0.71 \mathrm{~cm}$. Both thigh and calf 
circumference measurements were determined to have a statistically significant correlation with body fat mass $(\mathrm{p}<0.01)$.

The average resting heart rate of the subjects was found to be $80.28 \pm 15.24$ beats $/ \mathrm{min}$. An increase in waist circumference tends to correspond to increased average resting heart rate values. Individuals with a waist circumference between 60 and $66 \mathrm{~cm}$ had an average resting heart rate of $80.78 \pm 12.69$ beats $/ \mathrm{min}$. while those whose waist circumference was between $76-84$ had a resting heart rate of $114.67 \pm 33.31$ beats $/ \mathrm{min}$. These data were determined to be statistically significant at a level of $p<0.01$. In order to determine among which groups of data this significance occurred, a "post hoc test" was performed: the results revealed that the fourth group (those with a waist circumference between $76-84 \mathrm{~cm}$ ) showed a significant difference $(\mathrm{p}<0.01)$ from the other groups.

Vertical jump heights were examined according to the waist circumferences of the subjects; the average jump height of all the subjects was determined to be $33.87 \pm 7.22 \mathrm{~cm}$. The vertical jump height values were determined not to be statistically significant with respect to waist circumference $(\mathrm{p}<0.05)$. In a study on elite level handball players (Yıldirım ve Özdemir, 2010), it was suggested that waist circumference measurements have an effect on vertical jump heights. This discrepancy with the literature may result from the groups involved in the study.

When the body mass of the subjects was classified according to waist circumference measurements, a corresponding increase in body mass was observed with increased waist circumference. Accordingly, these values were determined to exhibit a statistically significant difference $(\mathrm{p}<0.01)$.

The body fat percentages of all the test subjects based on waist circumference were taken into consideration, with the average BFP calculated to be $22.92 \pm 5.54 \%$. Body fat percentage levels showed an increase that corresponded with increased waist circumference. Subjects with a waist circumference between 60 and $66 \mathrm{~cm}$ had an average body fat percentage of $18.37 \pm 3.48 \%$, while those with a waist circumference of 85 or greater had an average body fat percentage of $38.55 \pm 0.77 \%$. These values were found to show a significant increase with increased waist circumference $(\mathrm{p}<0.01)$. Şanlier $(2005)$ in his study reported that there was a significant correlation between body fat percentage and waist circumference.

The average body fat mass for all the subjects was $12.99 \pm 5.47 \mathrm{~kg}$. These values, as generally observed, showed a corresponding increase with waist circumference. Subjects with the lowest waist circumference measurements (between 60 and $66 \mathrm{~cm}$ ) had an average body fat mass of $8.98 \pm 2.38 \mathrm{~kg}$, while those with the greatest waist circumferences had an average average body fat mass of $31.55 \pm 1.48 \mathrm{~kg}$. These data exhibited a statistically significant difference $(\mathrm{p}<0.01)$.

The subjects involved in the study were found to have an average Body Mass Index of $21.27 \pm 3.24 \mathrm{~kg} / \mathrm{m} 2$. When these values were examined according to waist circumference measurements, it was found that individuals with the lower waist circumference $(60-66$ $\mathrm{cm}$ ) had a BMI of $18.81 \pm 1.58 \mathrm{~kg} / \mathrm{m} 2$, while that of subjects with the largest waist circumference ( $85 \mathrm{~cm}$ and above) was $32.85 \pm 1.34 \mathrm{~kg} / \mathrm{m} 2$. This increase was found to be statistically significant at a level of $\mathrm{p}<0.01$. In their study examining 330 individuals, Hodge et al. (1993) found a positive correlation between waist circumference and BMI and waist-to-hip ratio (WHR). Yardımcı and Özçelik (2006) reported a correspondence between increase in BMI and waist circumference and a positive correlation between the two parameters. Their research findings support the data of the present study. 


\section{References}

1. F.F. Çolakoglu, Ö. Şenel, Sekiz haftalık aerobik egzersiz programının sedanter orta yaşlı bayanların vücut kompozisyonu ve kan lipidleri üzerindeki etkileri. Spormetre, Ankara Üniversitesi Beden Egitimi ve Spor Bilimleri Dergisi, 1, 56-61 (2003).

2. N. Sanlıer, Gençlerde biyokimyasal bulgular,antropometrik ölçümler, vücut bilesimi, beslenme ve fiziksel aktivite durumlarının degerlendirilmesi. Gazi Egitim Fakültesi Dergisi, 25, 47-73 (2005).

3. E. Şanlı, Ögretmenlerde Fiziksel Aktivite Düzeyi- Yas, Cinsiyet ve Beden Kitle İndeksi İliskisi. Yüksek Lisans Tezi. Gazi Üniversitesi Saglık Bilimleri Enstitüsü. Ankara (2008).

4. J.E.L Carter, B.H. Heath, Somatotyping-Development and Application, Cambridge University Press. (1990).

5. N. Erkan, Yaşam Boyu Spor, Bağırgan Yayımevi, Ankara (1998).

6. T. BOSİ BAĞCI, Yaşlılarda Antropometri, Turkish Journal of Geriatrics, Geriatri 6 (4), 147-151 (2003).

7. Y. Sevim, Antrenman Bilgisi, Tutibay Ltd.Ști Ankara (1997).

8. R.R. Wolfe, Fat metabolism in exercise. Adir Exp Bial; 441:147-56 (1998).

9. T. Smith, B. Smith, M. Davis, Predictors of Physical Fitness in a Collage Sample. Percept Mat Skills;1:1009-10 (2000).

10. E.A. Galliven, A. Singh, D. Michelson, Hormonal and metabolic responses to exercise across time of day and menstrual cycle phase. J Appl Physiol; 85:1822-1831(1997)

11. B. Kannin, D. Phil, The Effect of Short- vs. Long- Bout Exercise on Mood, VO2max, and Percent Body Fat. Preventive Medicine;40:92-98 (2005).

12. R.S. Gibson Principles of Nutritional Assessment. Oxford University Press, New York(1990).

13. A. Sarria, LA. Moreno, LA. Garcia-Clop, S. Fleta, MP. Morellan, M. Bueno, Body mass index ,triceps skinfold and waist circumference in screening for adiposity in male children and adolescent. Acta Pediatr; 90: 387-92 (2001)

14. M. Adaş, N. Özbey, N. Metin, H. Yaraşir, R. Kazancioğlu, Ş. Molvalilar, E. Sencer, Y.Orhan, Șișman kadinlarda viseral yağ indeksi ve metabolik risk göstergeleri ile ilişkisi, İst. Tıp Fak. Mecmuası, 62: 3 (1999)

15. A. Wade, The F.A. Guide To Training And Coaching Heineman, London (1979).

16. C. İşlegen, "Değişik Liglerde Oynayan Bolgesel Profesyonel FutbolTakımlarının Fiziksel ve Fizyolojik Profilleri”, Spor Bilimleri Dergisi, 22 (2), 83-93. (1987).

17. S. Temoçin, R.O. Ek, A. Tekin, "Futbolcularda Surat ve Dayanıklılığın Solunumsal kapasite uzerine etkisi” SPORMETRE Beden Eğitimi ve Spor Bilimleri Dergisi, 2 (1), 31-35 (2004).

18. H. Eker, Y.S. Ağaoğlu, F.Albay, "Niğde Universitesindeki 20-25 Yaş Arası Futbol Oynayan,Futbolu Bırakan ve Duzenli Spor Yapmayan Oğrencilerin Solunum ve Antropometrik Parametrelerinin İncelenmesi” SPORMETRE Beden Eğitimi ve Spor Bilimleri Dergisi,1 (2), 89-97 (2003).

19. G. Pekcan, Şişmanlığın Tanımı ve Saptanması. III. Uluslar arası Beslenme ve Diyetetik Kongresi, Obezite Sempozyumu, Hacettepe Üniversitesi Beslenme ve Diyetetik Bölümü, 93-104, Ankara (2000).

20. S. Küçükkömürler, Yurtlarda Kalan Öğrencilerin Şişmanlık Durumları Ve Uyguladıkları Diyet Örnekleri. Mesleki Eğitim Dergisi, 4 (7): 61-74 (2001)

21. P. Bilgiç, Sporcu ve Sporcu Olmayan Bireylerin Vücut Kompozisyonu ve Beslenme Durumları ile Serum Leptin Düzeylerinin Değerlendirilmesi. Hacettepe Üniversitesi Sağlık Bilimleri Enstitüsü Toplu Beslenme Sistemleri Programı Bilim Uzmanlığı Tezi, Ankara. (2003). 
22. G. Pekcan, S.Yücecan, M. Tayfur, K. Kayakırılmaz, N. Rakıcıŏlu, S. Mercanlıgil, G. Eroğlu, Dietary Intakes and Nutritional Status of Non-Institutionalized Elderly, Age and Nutrition (abstract), 3(2):139 (1992).

23. RG. Bowden, BA. Lanning, EI. Doyle, HM. Johnston, EI.Nassar, B. Slonaker, G. Scanes, C. Rasmussen, Comparison of body composition measures to dual-energy xray absorptiometry. J Exercise Physiol;8:1-9 (2005).

24. A. Ergün, Vücut Kompozisyonunun belirlenmesi (15. Bölüm) Yavuzer S. Fizyoloji pratik klavuzu, Antıp AȘ. Yayınları, 91-99 (1999)

25. YS.Biçer, İ. Peker, Y. Savucu, Kalp Tek Damar T1kanıklığı Olan Kadın Hastalarda Planlanmış Düzenli Yürüyüşün Vücut Kompozisyon Değerleri Üzerine Etkisi, Fırat Üniversitesi Sağlık Bilimleri Tıp Dergisi, Cilt 19, 4, 241-248 (2005).

26. E. Zorba, R.Yaman, S. Yıldırım, Ö. Saygın, 18-24 yaş Grubu Sedanter Bayan Öğrencilerde 8 haftalık Step Uygulamasının Bazı Fiziksel Uygunluk ve Antropometrik Değerlere Etkisi, Gazi Beden Eğitimi ve Spor Bilimleri Kongresi, Ankara (2000).

27. F. F. Çolakoğlu, S. Karacan, Genç Bayanlar İle Orta Yaş Bayanlarda Aerobik Egzersizin Bazı Fizyolojik Parametrelere Etkisi. Kastamonu Eğitim Dergisi, 14 (1) 277-284 (2006).

28. B.Şimşek, H. Ertan, AS. Göktepe, K. Yazıcıŏglu, Bayan Voleybolcularda Diz Kas Kuvvetinin Sıçrama Yüksekliğine Etkisi. Egzersiz, 1(1): 36-43. (2007)

29. Y. Polat Y, Çınar V., Şahin M., Pepe O. (2003). 14 Yaş Çocukların Fiziksel Uygunluk Düzeyleri İle Antropometrik Özelliklerinin İncelenmesi. İ.Ü. Spor Bilimleri Dergisi, $11 ; 3$ (ÖS), 127-130.

30. T. Fonong, Risk factors for 5 year mortality in older adults the cardiovascular health study. JAMA, 279, 585-592 (1998)

31. Ø. Rognmo, E. Hetland, J. Helgerud, J. Hoff, SA. Slørdahl, High intensity aerobic interval exercise is superior to moderate intensity exercise for increasing aerobic capacity in patients with coronary artery disease. Eur J Cardiovasc Prev Rehabil, (3), 216-222 (2004).

32. WK. Hoeger, West Publishing Company, United States of America, Principles and Labs. 2nd Edition, 189 (1991).

33. ND. Parker, GR. Hunter, MS. Treuth, Effects of Strength Training on Cardiovascular Responses During a Submaximal Walk and A Weight Loaded Walking Test İn Older Females. J Cardiopulm Rehab. 16 (1), 56-62. (1991)

34. F. Erdoğan, H. Sarı, M. Terzioğlu. Farklı spor branşlarındaki sporcular ile sedenter kişilerin istirahat-egzersiz ve dinlenme solunum dolaşım parametrelerinin karsılaştırılması.Spor Hekim Derg.;16; 121-128. (1981)

35. T. Saka, Y. Yıldız, Ö F. Tekbaş, T. Aydın, Genç Erkeklerde Spor Okulu Eğitim Programının Bazı Antropometrik ve Fonksiyonel Testler Üzerine Etkisi.Niğde Üniversitesi Beden Eğitimi ve Spor Bilimleri Dergisi, 2, 1 (2008)

36. A. Blake, W.C. Miller, D.A. Brown, Adiposity Does Not Hinder the Fitness Response to Exercise Training in Obese Women, J. Sports Med. Phys. Fitness, 40(2):107-177 (2000).

37. B. Temur, Research Of The Effect Of Bone Mineral Density, Age, Height And Weight On Grip Strength. International Journal of Academic Research Part B,4(6), 169-175 (2012)

38. M.E. Alphan,. Obezitenin tedavisinde sağlıklı beslenme davranışı, Actual Medicine, 11(5): 26-40 (2003)

39. Amerikan Collage of Sports Medicine (A.C.S.M.) The Recommended Quantity and Quality of Exercise for Developing and Maintaining Cadionespiratory and Muscular Fitness in Healthy Adults. Med.Sci.Sport Exercise, 4 (3), 22 - 265. (1990). 
40. M. Amano, T. Kanda, H. Ue, and T. Moritani, Exercise training and autonomic nervous system activity in obese individuals. Med Science Sports Exercise;33:12871291( 2001)

41. K. Gökdemir, H. Koç, O. Yüksel. Aerobik antrenman programının üniversite öğrencilerinin bazı solunum ve dolaşım parametreleri ile vücut yağ oranı üzerine etkisi, Egzersiz, 1,145-149 (2007)

42. E. Zorba, Fiziksel Uygunluk, Gazi Kitabevi Tic Şti, 2. baskı, Ankara, 64. (2001)

43. İ. Koca, Yüzme Bilmeyip Yüzme Teknik Eğitimi Alan ve Üniversite Yüzme Takımında Yüzme Sporuyla Uğrasan 18-25 yas arasındaki Bayan ve Erkeklerde Üç Aylık Yüzme Antrenman Programının Ergospirometreyle Ölçülen Fizyolojik Fonksiyonlara Etkisi, Osmangazi Üniversitesi Sağlık Bilimleri Enstitüsü Fizyoloji A.B.D, Y.Lisans Tezi, (2003).

44. İ. Yıldırım, V. Özdemir, Üst Düzey Erkek Hentbol Oyuncularının Antropometrik Özelliklerinin Yatay ve Dikey Sıçrama Mesafesine Etkisi. Selçuk Üniversitesi Beden Eğitimi ve Spor Bilim Dergisi, 12 (1), 63-72 (2010).

45. A.M. Hodge, G.K. Dowse, P.Z. Zimmet, Association of body mass index and waisthip circumference ratio with cardiovascular disease risk factors in Mineronesian Naurans. Int. J. Obes., 17, 399-407 (1993).

46. H. Yardimci, AÖ. Özçelik, Ankara İli Gölbaşi İlçesinde Yetişkin Kadinlarin Antropometrik Ölçümleri Ve Beslenme Alişkanliklari Üzerinde Bir Araştirma, Ankara Üniversitesi Ev Ekonomisi Yüksekokulu Yayın No: 13, Ankara ( 2006). 